\title{
Effects of sumac and turmeric as feed additives on performance, egg quality traits, and blood parameters of laying hens
}

\author{
Hidir Gumus ${ }^{1 *}$, Mustafa Numan Oguz ${ }^{1}$, Kadir Emre Bugdayci ${ }^{1}$, Fatma Karakas Oguz ${ }^{1}$ \\ ${ }^{1}$ Mehmet Akif Ersoy University, Veterinary Medicine Faculty, Department of Animal Nutrition and Nutritional Disease, Burdur, Turkey.
}

\begin{abstract}
The objective of this study was to investigate the effects of sumac and turmeric on performance, egg quality traits, and blood parameters of laying hens. Forty Lohman Brown hens at 30 weeks of age were distributed into four groups, consisting of five replicates with two hens in each. The experiment lasted for 42 days. Laying hens were fed different basal diets in treatment groups and control groups. The groups consisted of hens fed a basal diet with $0.5 \%$ sumac, a basal diet with $0.5 \%$ turmeric, and a basal diet with $0.25 \%$ sumac $+0.25 \%$ turmeric. Hens were given ad libitum access to feed and water during the experiment. The results revealed that there were no statistically significant differences in terms of final body weight, egg production, egg weight, and feed intake after the groups were fed according to the diets as $0.5 \%$ sumac, $0.5 \%$ turmeric, and $0.25 \%$ sumac $+0.25 \%$ turmeric. Addition of turmeric increased egg production and egg weight, but reduced the feed conversion ratio compared with the control group. On the other hand, dietary supplementation with sumac decreased egg weight. Shape index, yolk index, albumen index, Haugh unit, and yolk color parameters were also not affected by dietary supplementation of turmeric and sumac. When layers were fed the $0.25 \%$ sumac $+0.25 \%$ turmeric-supplemented diet, yolk index was higher in number, but Haugh unit and albumen index were lower. Dietary addition of sumac and turmeric does not have any negative influence on performance and egg quality traits of laying hens. Dietary treatments do not significantly affect blood serum cholesterol, alanine aminotransferase (ALT), and aspartate aminotransferase (AST) levels. With the supplementation of turmeric, AST and ALT levels are higher in number among all the groups. Dietary sumac and turmeric can be added at $0.5 \%$ level to laying hen rations without changing animal performance.
\end{abstract}

Key Words: herbal extract, performance, poultry

\section{Introduction}

Sumac (Rhus coriaria) is a member of Anacardiaceae family. It grows in subtropical and temperate regions around the world, particularly in Africa and North America. It was used as a treatment for half a dozen different ailments in medieval medicine, primarily in Middle-Eastern countries, where sumac had been more readily available than in Europe. Now, it is widely used as a spice, also as an herbal remedy in traditional medicine due to its antifibrogenic, antifungal, anti-inflammatory, antimalarial, antimicrobial, antimutagenic, antioxidant, antithrombin, antitumorigenic, antiviral, cytotoxic, hypoglycaemic, leukopaenic, and atheroprotective effects (Capcarova et al., 2011). Its seeds

Received: June 23, 2017

Accepted: September 4, 2017

*Corresponding author: hdrgumus@gmail.com

Copyright (C) 2018 Sociedade Brasileira de Zootecnia. This is an Open Access article distributed under the terms of the Creative Commons Attribution License (http://creativecommons.org/licenses/by/4.0/), which permits unrestricted use, distribution, and reproduction in any medium, provided the original work is properly cited. are rich in gallic, benzoic, and L- ascorbic acids (Kheiri et al., 2015) and provide a good source of flavones such as myricetin, quercetin, and kaempferol. Sumac is rich in a number of minerals, yet some macrominerals are richer in quantity such as potassium, calcium, magnesium, and phosphorous. It is stated that sumac contains palmitic, oleic, and linoleic acids, which are important fatty acids for metabolism (Shabbir, 2012). Some studies have been carried out to determine the effects of sumac on broilers (Mansoub, 2011; Golzadeh et al., 2012; Ghasemi et al., 2014; Kheiri et al., 2015), laying hens (Arpasova et al., 2014), rabbits (Capcarova et al., 2011), rats (Saglam et al., 2014), and on egg composition (Gulmez et al., 2006; Galik et al., 2013).

Turmeric (Curcuma longa) is a rhizomatous herbaceous perennial plant of the ginger family, Zingiberaceae. It has been extensively used for giving color and flavor to foods. It is also used for the treatment of a variety of inflammatory conditions (Durrani et al., 2006; Kermanshahi and Riasi, 2006; Malekizadeh et al., 2012). Turmeric has been used to treat cough, fever, urinary disease, eczema, and parasitic skin diseases (Kermanshahi and Riasi, 2006). Zingiberaceae members have some phenolic materials 
which have anti-mutagenic and anti-oxidative effects. The antioxidative capacity of ginger has been associated with its ability to inhibit carcinogenesis by reducing oxidative stress (Abdullah et al., 2010). It has been previously stated that active ingredients such as tetrahydrocurcuminoids were found in turmeric (Osawa et al., 1995); curcumin, demethoxycurcumin, and bisdemethoxycutcumin have also been found in turmeric (Wuthi-udomler et al., 2000). Some studies have been carried out to find out the effects of curcumin on the performance of broilers (Suriya et al., 2012; Wang et al. 2016) and laying hens (Laganá et al., 2011; Park et al., 2012). The antioxidant effect of turmeric has already been reported in the case of broilers (Wang et al., 2016). This effect is closely related to the increase of catalase, hepatic superoxide dismutase, and glutathione peroxidase enzymes (Dono, 2013).

It is impossible to synthesize egg yolk pigment of laying hens; even so it can be carried from diet to yolk (Laganá et al., 2011). Composition of laying hen diets affects pigmentation of egg yolks (Cho et al., 2012). Some feed additives such as dietary corticosterone (Kim et al., 2015), dried carrot meal (Sikder et al., 1998), and canthaxanthin (Cho et al., 2012) have been used to change the color of egg yolk. Likewise, turmeric and sumac are used in foods as a coloring and flavoring agent (Wang et al., 2016).

Sumac and turmeric were separately placed in jars; each filled with oil and water for a week before the research. The color change in the jar filled with oil was higher than the one filled with water for both plants. In the light of this information, the objective of the current study was to determine the effects of using both sumac and turmeric as a combination or separately on the performance, some egg quality traits, and yolk color of laying hens.

\section{Material and Methods}

This study was carried out according to the ethical principles and was approved by the local Research Ethics Committee (case no. 93773921-020). The study was conducted in Burdur $\left(37^{\circ} 43^{\prime} \mathrm{N} ; 30^{\circ} 16^{\prime} \mathrm{E}\right)$, the transition region in the inner part of the western Mediterranean region in between the Mediterranean Sea. A total of forty Lohman Brown laying hens with uniform body weight at 30 weeks of age were distributed into four groups: one control and three dietary treatment groups, each containing five replicate groups of two hens. The study was carried out for six weeks (02/06/2015 to 03/19/2015). Sumac and turmeric were purchased from a local market. Hens were housed in wire cages $(30 \times 44 \times 44 \mathrm{~cm})$ which were of two-tier and three sides. Room temperature $\left(16 \pm 2{ }^{\circ} \mathrm{C}\right)$ was recorded daily and light program was regulated as $16 \mathrm{~h}$ of light/day throughout the study. Each cage was equipped with nipple drinker. Diets and water were provided ad libitum during the experimental period. The control group received basal diet (no supplement) throughout the experimental period. Treatment groups were, respectively, fed diets containing $0.5 \%$ sumac, $0.5 \%$ turmeric, and $0.25 \%$ sumac $+0.25 \%$ turmeric. Sumac and turmeric were added to treatment group feeds weekly. The diets were formulated as isonitrogenous and isoenergetic as NRC (1994) requirements (Table 1).

Nutrient composition of concentrated feeds was determined according to the AOAC (2003), crude fiber was determined by the methods of Crampton and Maynard (1938). The metabolizable energy levels of concentrated feeds (Table 2) were determined by the methods of Titus and Fritz (1971).

Hens were weighed individually at the beginning and end of the study. For each cage, eggs were counted daily and weighed weekly with an electronic balance at the same time to calculate hen-day egg production. Feed intake and feed conversion ratio (FCR) were determined weekly. Feed conversion ratio was calculated by determining the amount of feed consumed per kilogram of egg production and per kilogram of feed for a dozen eggs.

Egg quality was determined with ten eggs which were collected randomly from 09:30 to $12: 30 \mathrm{~h}$ from each replicate on two consecutive days every two-week period. Egg width $\left(E_{w}\right)$ and egg length $\left(E_{L}\right)$ were measured by digital caliper (Absolute digimatic caliper/series 500) to determine shape index $\left[\%=\left(\mathrm{E}_{\mathrm{w}} / \mathrm{E}_{\mathrm{L}}\right) \times 100\right]$.

The eggs were broken onto a glass-topped table; the albumen $\left(\mathrm{A}_{\mathrm{H}}\right)$ and the yolk $\left(\mathrm{Y}_{\mathrm{H}}\right)$ heights were measured with a tripod micrometer (Mitutoyo, no. 2050S-19, 0.01-20 mm;

Table 1 - Ingredients of basal diet

\begin{tabular}{lc}
\hline Ingredient & Amount $(\mathrm{g} / \mathrm{kg})$ \\
\hline Wheat & 140 \\
Corn & 334 \\
Sunflower meal & 207 \\
Soybean meal 48\% CP & 134 \\
Vegetable oil & 60 \\
Di calcium phosphate & 16 \\
Limestone & 100 \\
Salt & 3.5 \\
DL-methionine & 2 \\
L-lysine hydrocloride & 1 \\
Vitamin mineral premix ${ }^{1}$ & 2.5 \\
\hline CP - crude protein. & \\
${ }^{1}$ Vitamin and mineral premix provided per kilogram of diet: $12,000,000 \mathrm{IU}$ vitamin A; & \\
20,000 mg vitamin E; 50,000 mg manganese; 50,000 mg iron; 50,000 mg zinc; & \\
10,000 mg copper; 150 mg cobalt; 150 mg selenium.
\end{tabular}


Table 2 - Chemical composition of the diets ( $\mathrm{g} / \mathrm{kg}$ of dry matter)

\begin{tabular}{|c|c|c|c|c|c|c|c|}
\hline Group & Dry matter & Ash & Organic matter & Crude protein & Ether extract & Crude fiber & $\begin{array}{c}\text { Metabolizable } \\
\text { energy }(\mathrm{kcal} / \mathrm{kg})\end{array}$ \\
\hline Control & 924.4 & 93.5 & 830.9 & 187.5 & 72.6 & 45.7 & 2537.65 \\
\hline $0.5 \%$ sumac & 920.9 & 94.0 & 826.9 & 181.5 & 68.0 & 53.5 & 2488.52 \\
\hline $0.25 \%$ sumac $+0.25 \%$ turmeric & 920.8 & 93.0 & 827.8 & 181.8 & 75.7 & 50.1 & 2521.90 \\
\hline
\end{tabular}

${ }^{1} \mathrm{MJ} / \mathrm{g}=133.06$ (crude protein) +232.91 (ether extract) -4.68 (crude fiber) +122.77 (nitrogen-free extract) (Titus and Fritz, 1971).

Kawasaki, Japan). To determine yolk index $\left[\mathrm{Y}_{\mathrm{I}}=\left(\mathrm{Y}_{\mathrm{H}} / \mathrm{Y}_{\mathrm{D}}\right)\right.$ $\times 100]$, albumen index $\left[\mathrm{A}_{\mathrm{I}}=\mathrm{A}_{\mathrm{H}} /\left[\left(\mathrm{A}_{\mathrm{L}}+\mathrm{A}_{\mathrm{w}}\right) / 2\right] \times 100\right]$, and Haugh Unit $\left[\mathrm{H}_{\mathrm{U}}=100 \log (\right.$ Albumen height $+7.57-1.7 \times$ Egg weight $\left.{ }^{0.37}\right)$ ] (Haugh, 1937), the albumen length $\left(\mathrm{A}_{\mathrm{L}}\right)$ and width $\left(\mathrm{A}_{\mathrm{w}}\right)$ and the yolk diameter $\left(\mathrm{Y}_{\mathrm{D}}\right)$ were measured using a digital caliper (Yalçın et al., 2014).

Egg yolk color was measured with one of the 15 bands of the "Roche Yolk Color Fan". At the end of the study, blood samples were collected from the brachial vein (vena cutanea ulnaris $)$ in a glass tube $(16 \times 100 \mathrm{~mm})$ and centrifuged to obtain serum. Supernatant was collected in a $1.5-\mathrm{mL}$ Eppendorf tube and stored at $-20^{\circ} \mathrm{C}$ for biochemical assays. Levels of cholesterol, alanine aminotransferase (ALT), and aspartate aminotransferase (AST) were measured from blood serum.

Statistical analysis was carried out with SPSS program (Statistical Package for the Social Sciences; Inc., Chicago, IL, USA). All data were subjected to statistical analysis using one-way ANOVA. Differences among the groups were calculated using Duncan test (Dawson and Trapp, 2001). Level of significance was taken as $\mathrm{P}<0.05$.

\section{Results}

The inclusion of $0.5 \%$ sumac to the diet had no significant effect $(\mathrm{P}>0.05)$ on final body weight, feed intake, and FCR (Table 3). Final body weight and feed intake increased in number in $0.5 \%$ sumac treatment compared with the control group $(\mathrm{P}>0.05)$. Feed intake and FCR were higher (3.9 and 5.8\%, respectively) for laying hen diets containing sumac than the control diet. The results of the study stated that egg production and egg weight were not influenced statistically by dietary addition of sumac at $0.5 \%$ level. Egg production was found as 98.81, 94.94, 94.05, and 91.66 for $0.5 \%$ turmeric, $0.5 \%$ sumac, $0.25 \%$ turmeric $+0.25 \%$ sumac, and the control group, respectively. Egg production was higher (3.45\%); however, egg weight was lower $(1.4 \%)$ for hens fed $0.5 \%$ sumac than fed the control diet.

Turmeric had a statistically nonsignificant effect on final body weight, feed intake, and FCR (Table 3). Feed conversion ratio was found as $2.02,2.06,2.08$, and 2.20 for $0.5 \%$ turmeric, $0.25 \%$ sumac $+0.25 \%$ turmeric, control group, and $0.5 \%$ sumac, respectively. Feed intake tended to be higher for hens fed turmeric than fed the control diet. There was no significant differences $(\mathrm{P}>0.05)$ in egg production and egg weight.

Internal egg quality parameters were not affected by dietary supplementation (Table 4 ). The shape index was lower in number for laying hens fed $0.5 \%$ turmeric compared with the other diets. Albumen index was not significantly influenced by the dietary treatments. The yolk index was $6.8 \%$ higher in $0.5 \%$ sumac and $4.5 \%$ higher in $0.25 \%$ sumac $+0.25 \%$ turmeric treatments than in the control group $(\mathrm{P}>0.05)$. Haugh unit was $0.5 \%$ lower in $0.5 \%$ turmeric treatment than in the control group at the end of study. Parameters of yolk color did not differ among the groups $(\mathrm{P}>0.05)$. Yolk color was higher at the sixth week than at the second week among all groups in the study.

There were no significant differences among treatments in terms of total cholesterol, ALT, and AST (Table 5). The turmeric treatment presented the highest ALT and AST levels among all groups.

Table 3 - Effects of different levels of sumac and turmeric on performance of laying hens

\begin{tabular}{|c|c|c|c|c|c|}
\hline Item & Control & $0.5 \%$ sumac & $0.5 \%$ turmeric & $0.25 \%$ sumac $+0.25 \%$ turmeric & P-value \\
\hline Initial body weight (g) & 1634.12 & 1709.00 & 1693.25 & 1658.87 & 0.32 \\
\hline Final body weight $(\mathrm{g})$ & 1775.09 & 1841.00 & 1893.00 & 1785.75 & 0.22 \\
\hline Feed intake $(\mathrm{g})$ & 117.60 & 122.27 & 119.80 & 117.03 & 0.54 \\
\hline Feed conversion ratio ( $\mathrm{g}$ feed/g egg) & 2.08 & 2.20 & 2.02 & 2.06 & 0.28 \\
\hline Feed conversion ratio ( $\mathrm{kg}$ feed/dozen egg) & 1.54 & 1.54 & 1.45 & 1.49 & 0.42 \\
\hline Egg weight $(\mathrm{g})$ & 56.38 & 55.61 & 59.37 & 56.95 & 0.20 \\
\hline
\end{tabular}




\section{Discussion}

Final body weight, feed intake, and FCR were not significantly affected by addition of sumac $(\mathrm{P}>0.05)$ in the current study. Final body weight and feed intake were increased in number in $0.5 \%$ sumac treatment compared with the control group ( $\mathrm{P}>0.05)$. Feed intake might have increased due to the enhancing of taste or feed palatability with addition of sumac to ration (Alloui et al., 2014). Similarly, Arpasova et al. (2014) indicated that final body weight and feed intake were relatively higher in the addition of $1 \%$ sumac to laying hen diet than in the control group. Regarding feed intake and final body weight, sumac enhances the levels of absorbed amino acids because of its decreasing effect of harmful bacteria population (Kheiri et al., $2015)$. In the present study, FCR was higher (5.8\%) in $0.5 \%$ sumac than in the control group. In contrast, Ghasemi et al. (2014) indicated that using $0.2 \%$ sumac extract in broiler hen diet significantly affected FCR $(\mathrm{P}<0.05)$. They found that FCR was lower $(5.3 \%)$ in sumac group than in the control group. This positive effect is probably connected with the content of active materials (cinnamaldehyde and ugenol) found in sumac, which provide greater utilization of feed resulting in enhanced growth (Mansoub et al., 2011).
Inconsistent with the present study, Monsoub et al. (2011) reported that feed intake and FCR were significantly affected $(\mathrm{P}<0.05)$ in laying hen diet containing $2 \%$ sumac. The results of the current study showed that egg production and egg weight were not statistically influenced by dietary addition of sumac at $0.5 \%$ level. Egg production was higher (3.45\%); however, egg weight was lower (1.4\%) in $0.5 \%$ sumac than in the control group. Similarly, Arposova et al. (2014) recorded that egg production rate varied from 135.5 to $136.9 \mathrm{~g}$ and egg weight rate ranged from 57.35 to $58.10 \mathrm{~g}$ in laying hens fed sumac.

The results showed that using turmeric did not significantly affect final body weight, feed intake, and FCR (Table 3). Wang et al. (2016) indicated that daily feed intake increased by addition of 100 and $200 \mathrm{mg} / \mathrm{kg}$ turmeric rhizome extract to broilers; but daily feed intake decreased by addition of $300 \mathrm{mg} / \mathrm{kg}$. In the current study, final body weight, feed intake, and FCR ( $\mathrm{g}$ feed/g egg) ranged from $1775.09 ; 117.60 ; 2.08$ to $1893.00 ; 119.80 ; 2.02$, respectively, according to the control group $(\mathrm{P}>0.05)$. These differences are consistent with the results of Moeini et al. (2011) and Malekizadeh et al. (2012), who added $3 \%$ turmeric rhizome powder to laying hen diet. Feed intake increased and FCR decreased. In another study

Table 4 - Effects of different levels of sumac and turmeric on internal egg quality of laying hens

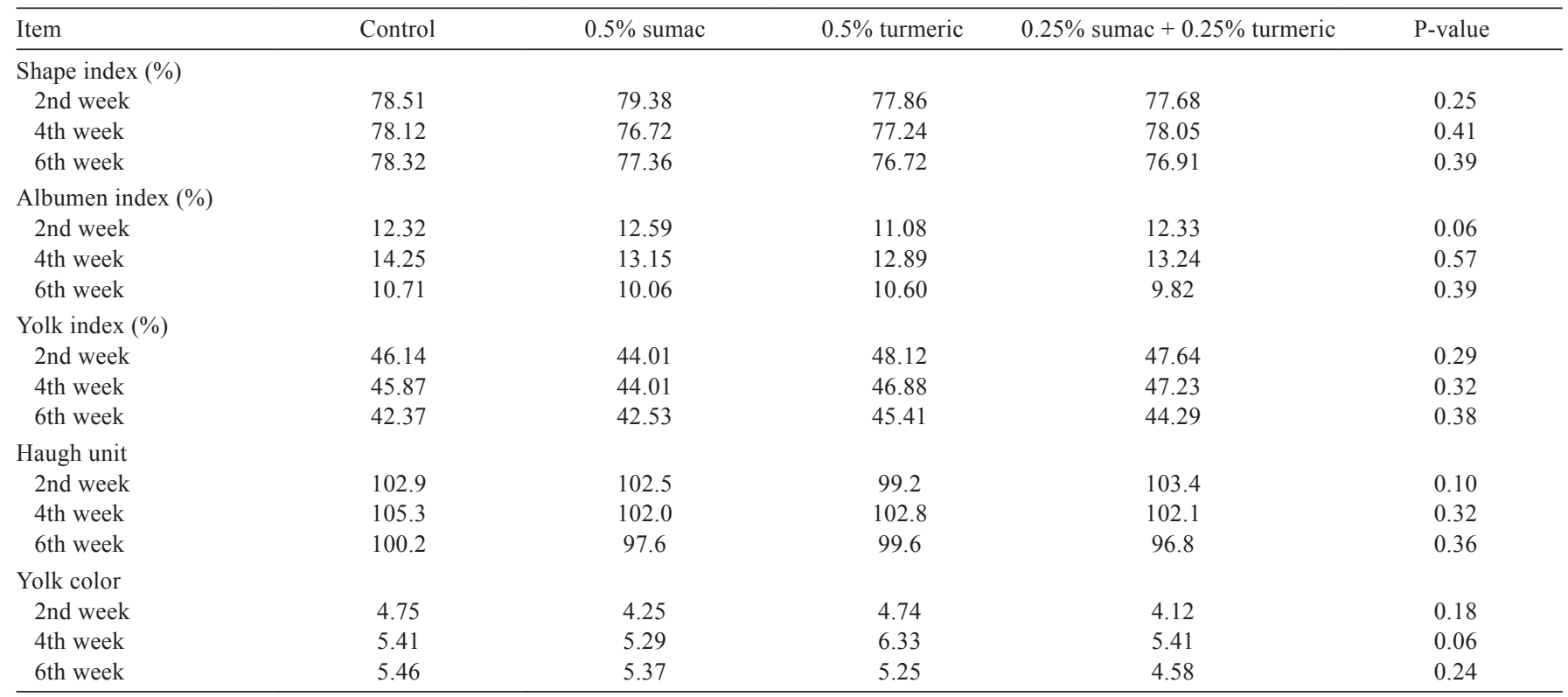

Table 5 - Effects of different levels of sumac and turmeric on blood parameters of laying hens

\begin{tabular}{|c|c|c|c|c|c|}
\hline Item & Control & $0.5 \%$ sumac & $0.5 \%$ turmeric & $0.25 \%$ sumac $+0.25 \%$ turmeric & P-value \\
\hline Total cholesterol (mg/dL) & 117.36 & 115.12 & 123.87 & 126.00 & 0.96 \\
\hline ALT & 4.75 & 4.87 & 5.00 & 4.37 & 0.49 \\
\hline AST & 97.30 & 98.92 & 103.90 & 100.83 & 0.83 \\
\hline
\end{tabular}

ALT - alanine aminotransferase; AST - aspartate aminotransferase. 
(Laganá et al., 2011), feed intake and FCR were reduced by addition of $2 \%$ turmeric rhizome powder to laying hen diet. According to Durrani et al. (2006), the increase in body weight was caused by the use of turmeric that can stimulate protein synthesis. As observed in this study, feed intake tended to be higher in the control group and FCR was the lowest in $0.5 \%$ turmeric among all the groups. Because of increased incretion of enzymes such as amylase, trypsin, chymotrypsin, and lipase, FCR might be improved by turmeric-supplemented diets of laying hens (Wang et al., 2016). Moreover, the reason of feed intake increment might be due to turmeric special aroma. The specific aroma could be resulted from volatile essential oil in turmeric such as a-phellandrene, 1:8 cineol, zingiberene, arcurcumene, turmerone, ar-turmerone, b-sesquiphellandrene, curlone, and dehydrozingerone (Chatterjee et al., 2000). Park et al. (2012) indicated that feed intake was $0.7 \%$ higher in the control group $(\mathrm{P}>0.05)$, coinciding with the finding of the current study in which the addition of turmeric powder to laying hen diet enhanced feed intake by $1.9 \%$. Radwan et al. (2008) reported that feed intake was $1 \%$ higher for laying hens fed turmeric-supplemented diets. There were no significant differences $(\mathrm{P}>0.05)$ in egg production and egg weight in the present study, which is in accordance with other studies (Incharoen and Yamauchi, 2009; Laganá et al., 2011; Zhao et al., 2011), but the current study does not comply with other studies (Malekizadeh et al., 2012; Park et al., 2012). Malekizadeh et al. (2012) indicated that egg production increased $(\mathrm{P}<0.05)$, but egg weight decreased insignificantly by addition of turmeric rhizome powder to laying hen diets. According to the authors, turmeric might enhance digestive tract performance in laying hens resulting in the improvement of egg production. Park et al. (2012) showed that turmeric powder affected egg production significantly, but not egg weight. Radwan et al. (2008) indicated that production and mass of egg increased by addition of turmeric due to the fact that uterus media could have been improved (especially the site of calcium deposit) and result in enhanced shell weight and thickness.

According to the results of this study, sumac and turmeric do not have any significant effect on internal egg quality traits (Table 4). The results obtained from the study complies with Laganá et al (2011), who reported that internal egg quality traits were not influenced by dietary addition of turmeric. In the present study, Haugh unit and albumen index (\%) rates insignificantly decreased at the sixth week $(\mathrm{P}>0.05)$ due to decline of albumen height in all groups. These results on internal egg quality were not in accordance with Saraswati et al. (2013), who found that albumen height and egg protein significantly increased by addition of turmeric. According to Saraswati et al. (2013), increase in albumen showed that active substances in turmeric powder stimulated the growth of the epithelial cells and tubular gland cells in the magnum to synthesize and secrete albumen. Haugh unit decreased in number in $0.5 \%$ turmeric group (99.6) compared with the control group (100.2) at the end of the sixth week. In contrast with these results, Park et al. (2012) found that Haugh unit of the group fed $0.25 \%$ turmeric was highest among all groups $(\mathrm{P}<0.05)$. The yolk index was $6.8 \%$ higher in $0.5 \%$ sumac and $4.5 \%$ higher in $0.25 \%$ sumac +0.25 turmeric treatments than in the control group $(\mathrm{P}>0.05)$, which is in accordance with Incharoen and Yamauchi (2009), who reported that yolk index was insignificantly enhanced by the addition of dried fermented ginger.

Consumers want yolk color to be deep (Englmaierova et al., 2014). Therefore, some additives such as phytogenic are commonly used in laying hen rations to enrich yolk color. Carotenoids alter egg yolk color and are a source of red and yellow (xanthophylls) pigments (Englmaierova et al., 2014). However, laying hens cannot synthesize egg yolk pigments (Karaskova et al., 2015). Xanthophyll is attached to fat-soluble pigments in the feed (Yildırım et al., 2013). In the present study, there were no significant differences in yolk color. These results comply with Radwan et al. (2008), who reported that addition of turmeric to hen ration did not affect yolk color and Haugh unit, but it significantly increased yolk index. At the fourth week, addition of $0.5 \%$ turmeric powder increased yolk color by $17 \%$ compared with the control diet, which is in accordance with Riasi et al. (2012), who reported that the effect of dietary addition of turmeric rhizome powder is remarkable $(\mathrm{P}<0.05)$ on yolk color rate after four weeks of study. According to the authors, enhancement of yolk color could result from the yellowish pigment of turmeric (curcuminoids, curcumin, and its related compounds). At the sixth week, yolk color was lower about $4 \%$ in laying hens fed $0.5 \%$ turmeric compared with the control group ( $>0.05)$. On the other hand, Park et al. (2012) observed that yolk color increased significantly by the addition of $0.5 \%$ dietary turmeric powder.

Dietary treatments did not affect total cholesterol, ALT, and AST significantly (Table 5). Park et al. (2012) reported that serum total cholesterol concentration was not significantly affected by the addition of turmeric. In a study carried out with turmeric for laying hens, it was reported that cholesterol decreased significantly (Kermanshahi and Riasi, 2006); the authors reported that turmeric could be useful in the management of arteriosclerosis. Ramirez et al. (1999) reported that turmeric decreased lipid peroxidation due to its antioxidant effects and increased plasma vitamin $\mathrm{E}$ in 
rabbits. Miquel et al. (2002) indicated that curcumin may support anti-atherogenic action of tocopherol. Curcumin is the main phenolic antioxidant that may enhance the effects of vitamin E. Current results indicate that total cholesterol was at its lowest rate in $0.5 \%$ sumac, but highest in $0.5 \%$ turmeric and $0.25 \%$ sumac $+0.25 \%$ turmeric treatments compared with the control group. Rates of ALT and AST increased by the addition of turmeric and sumac separately. It is likely that sumac has hypocholesterolemic effects due to its polyphenolic components, especially D-limonene (1-methyl-4-(1-methylethenyl)-cyclohexane), which is monocyclic monoterpene component of sumac. Polyphenols depress the reverse-cholesterol transport, reduce the intestinal cholesterol absorption, and even increase bile acid excretion (Kheiri et al., 2015). Malekizadeh et al. (2012) reported that addition of $1 \%$ turmeric in laying hen diets decreased cholesterol and ALT, but increased AST. Furthermore, they found the same results as Riasi et al. (2012), who reported that turmeric decreased total cholesterol in laying hens. Rate of cholesterol catabolism could be enhanced, thereby increasing in hepatic cholesterol-7 $\alpha$-hydroxylase activity (Riasi et al., 2012). Radwan et al. (2008) found that addition of $1 \%$ turmeric to laying hens diets decreased cholesterol compared with the control group; however, AST and ALT were not affected.

\section{Conclusions}

The addition of sumac and turmeric supplementation has no significant effects on performance, egg quality traits, and blood parameters of laying hens. Dietary sumac and turmeric can be added at $0.5 \%$ level to laying hen rations without changing animal performance.

\section{References}

Abdullah, S.; Abidin, S. A. Z.; Murad, N. A.; Makpol, S.; Ngah, W. Z. W. and Yusof, Y. A. M. 2010. Ginger extract (Zingiber officinale) triggers apoptosis and G0/G1 cells arrest in HCT 116 and HT 29 colon cancer cell lines. African Journal of Biochemical Research 4:134-142.

Alloui, M. N; Agabou, A. and Alloui, N. 2014. Application of herbs and phytogenic feed additives in poultry production-A Review. Global Journal of Animal Scientific Research 2:234-243.

AOAC - Association of Official Analytical Chemists. 2003. Official methods of analysis. 17th ed. 2nd rev. Gaithersburg, MD, USA.

Arpasova, H. I.; Kacaniova, M.; Branislav, G.; Cubon, J. and Mellen, M. 2014. The effect of oregano essential oil and Rhus coriaria L. on selected performance parameters of laying hens. Animal Science Biotechnology 41:12-16.

Capcarova, M.; Slamecka, J.; Abbas, K.; Kolesarova, A.; Kalafova, A.; Valent, M.; Filipejova, T.; Chrastinova, L.; Ondruska, L. and Massanyi, P. 2011. Effects of dietary inclusion of Rhus coriaria on internal milieu of rabbits. Journal Animal Physiology and Animal Nutrition 96:459-465. doi: 10.1111/j.1439-0396.2011.01164.

Chatterjee, S.; Variyar, P. S.; Gholap, A. S.; Padwal-Deasi, S. R. and Bongirwar, D. R. 2000. Effect of g-irradiation on the volatile oil constituents of turmeric (Curcuma longa). Food Research International 33:103-106.

Cho, J. H.; Zhang, Z. F. and Kim, I. H. 2012. Effects of canthaxanthin on egg production, egg quality, and egg yolk color in laying hens. Journal Agricultural Science 5:269-274.

Crampton, E. W. and Maynard, L. A. 1938. The relation of cellulose and lignin content to nutritive value of animal feeds. Journal of Nutrition 15:383-395.

Dawson, B. and Trapp, R. G. 2001. Basic and clinical biostatistics. 3th ed. Lange Medical Books McGraw-Hill Medical Publishing Division, New York.

Dono, N. D. 2013. Turmeric (curcuma longa linn.) supplementation as an alternative to antibiotics in poultry diets. Wartazoa 23:41-49.

Durrani, F. R.; Ismail, M.; Sultan, A.; Suhail, S. M.; Chand N. and Durrani, Z. 2006. Effect of different levels of feed added turmeric (Curcuma longa) on the performance of broiler chicks. Journal Agricultural Biology and Environmental Statistics 1:9-11.

Englmaierova, M.; Bubanco, I. and. Skrivan, M. 2014. Carotenoids and egg quality. Acta Fytotechnica et Zootechnica 17:55-57.

Galik, B.; Henrita, A.; Daniel, B.; Rolinec, M.; Simko, M.; Miraslav, J. and Ivana N. 2013. The effect of dietary Rhus coriaria L. supplementation on fatty acids composition in the table eggs. Acta Fytotechnica et Zootechnica 16:49-52.

Ghasemi, R.; Faghani, M.; Reza, J. P.; Khonmirzaiee, N. and Rahimian, Y. 2014. Using sumac (Rhus coriaria L.) extract affect performance and intestinal characteristics of broiler chicks. Journal Agricultural Science 4:442-445.

Golzadeh, M.; Farhoomand, P. and Daneshyar, M. 2012. Dietary Rhus coriaria L. powder reduces the blood cholesterol, VLDL-c and glucose, but increases abdominal fat in broilers. South Africa Journal Animal Science 42:398-405.

Gulmez, M.; Oral, N. and Vatansever, L. 2006. The effect of water extract of sumac (Rhus coriaria L.) and lactic acid on decontamination and shelf life of raw broiler wings. Poultry Science 85:1466-1471.

Haugh, R. R. 1937. The Haugh Unit for measuring egg quality. U. S. Egg Poultry Magazine 43:522-555.

Incharoen, T. and Yamauchi, K. 2009. Production performance, egg quality and intestinal histology in laying hens fed dietary dried fermented ginger. International Journal of Poultry Science 8:1078-1085.

Karaskova, K.; Suchy, P. and Strakova, E. 2015. Current use of phytogenic feed additives in animal nutrition: a review. Czech Journal Animal Science 60:521-530.

Kermanshahi, H. and Riasi, A. 2006. Effect of turmeric rhizome powder and soluble NSP degrading enzyme on some blood parameters of laying hens. International Journal of Poultry Science 5:494-498.

Kheiri, F.; Rahiman, Y. and Nasr, J. 2015. Application of sumac and dried whey in female broiler feed. Archives Animal Breeding 58:205-210

Kim, Y. H.; Kim, J.; Yoon, H. S. and Choi, Y. H. 2015. Effects of dietary corticosterone on yolk colors and eggshell quality in laying hens. Asian-Australasian Journal of Animal Sciences 28:840-846.

Laganá, C. I.; Pizzolante, C. C.; Saldanha, E. S. P. B. and Moraes, J. E. 2011. Turmeric root and annato seed in second-cycle layer diets: Performance and egg quality. Brazilian Journal Poultry Science 13:171-176.

Malekizadeh, M.; Moeini, M. M. and Ghazi, S. H. 2012. The effects of different levels of ginger (Zingiber officinale Rosc) and 
turmeric (Curcuma longa Linn) rhizomes powder on some blood metabolites and production performance characteristics of laying hens. Journal Agricultural Science Technology 14:127-134.

Mansoub, N. H. 2011. Effect of different levels of sumac powder (Rhus coriaria L.) on performance, carcass and blood parameters of broiler chickens. Annual Biology Research 2:647-652.

Miquel, J.; Bernard A.; Sempere, J. M.; Diaz-Alperi, J. and Ramirez, A. 2002. The curcuma antioxidants: Pharmacological effects and prospects for future clinical use. A review. Archives of Gerontology and Geriatrics 34:37-46.

Moeini, M. M.; Malekizadeh, M. and Ghazi, S. 2011. The effects of different levels of ginger and turmeric rhizomes powder on productive performance characteristics of laying hens. Researches of the First International Conference (Babylon and Razi Universities).

NRC - National Research Council. 1994. Nutrient requirements of poultry. NRC, Washington, DC, USA.

Osawa, T.; Sugiyama, Y.; Inayoshi, M. and Kawakisi, S. 1995. Antioxidative activity of tetrahydrocurcuminoids. Bioscience, Biotechnology, and Biochemistry 59:1609-1611.

Park, S. S.; Kim, J. M.; Kim, E. J.; Kim, H. S.; Kim, B. and Kang, C. W. 2012. Effects of dietary turmeric powder on laying performance and egg qualities in laying hens. Korean Journal Poultry Science 39:27-32.

Radwan, N. L.; Hassan, E. M. Q. and Fayek, H. M. 2008. Effect of natural antioxidant on oxidative stability of eggs and productive and reproductive performance of laying hens. International Journal of Poultry Science 7:134-150.

Ramirez, M. C.; Mesa, M. D.; Aguilera, M. C.; Quiles, J. L.; Baro, L.; Ramirez, C. L.; Martinez E. and Gil, A. 1999. Oral administration of a turmeric extract inhibits LDL oxidation and has hypocholesterolemic effects in rabbits with experimental atherosclerosis. Atherosclerosis 147:371-378.

Riasi, A.; Kermanshahi, H. and Mahdavi, H. 2012. Production performance, egg quality and some serum metabolites of older commercial laying hens fed different levels of turmeric rhizome (Curcuma longa) powder. Journal Medical Plants Research 6:2141-2145.

Saglam, M.; Serhat, K.; Mükerrem, H.; Hasan, H. E. and Ekrem, K. 2014. Effect of sumac extract on serum oxidative status, RANKL/
OPG system and alveolar bone loss in experimental periodontitis in rats. Journal of Applied Oral Science 23:33-41.

Saraswati, T. R.; Manalu, W.; Ekastuti, D. R. and Kusumorini, N. 2013. The role of turmeric powder in lipid metabolism and its effect on quality of the first quail's egg. Journal of the Indonesian Tropical Animal Agriculture 38:123-130.

Shabbir, A. 2012. Rhus coriaria linn, a plant of medicinal, nutritional and industrial importance: a review. Journal of Animal and Plant Sciences 22:505-512.

Sikder, A. C.; Chowdury, S. D.; Rashid, M. H.; Sarker, A. K. and Das, S. C. 1998. Use of dried carrot meal in laying hem diet for egg yolk pigmentation. Asian-Australasian Journal of Animal Sciences 11:239-244.

Suriya, R., Zulkifli, I. and Alimon, A. R. 2012. The effect of dietary inclusion of herbs as growth promoter in broiler chickens. Journal of Animal and Veterinary Advances 11:346-350.

Titus, H. W. and Fritz, J. C. 1971. Percentage multipliers for computing metabolizable energy values, for chickens, of some feedstuffs used in the feeding of poultry. In: The scientific feeding of chickens. 5th ed. Interstate, Danville, IL.

Wang, D.; Huifang, H.; Zhou, L.; Wei, L.; Hanlin, Z.; Guanyu, H.; Jia, L. and Lin, H. 2016. Effects of dietary supplementation with turmeric rhizome extract on growth performance, carcass characteristics, antioxidant capability, and meat quality of Wenchang broiler chickens. Italian Journal Animal Science 14:344-349.

Wuthi-udomler, M.; Grisanapan, W.; Luanratana, O. and Caichompoo, W. 2000. Anti-fungal activities of plant extracts. The Southeast Asian Journal of Tropical Medicine and Public Health 31:178-182.

Yalçın, S.; Yalçın S.; Onbaşıla, İ.; Eser, H. and Şahin, A. 2014. Effects of dietary yeast cell wall on performance, egg quality and humoral immune response in laying hens. Ankara Üniversitesi Veteriner Fakültesi Dergisi 61:289-294.

Yıldırım, A.; Şekeroğlu, A.; Eleroğlu, H.; Şen, M. I. and Duman, M. 2013. Effects of Korean ginseng (Panax ginseng C.A. Meyer) root extract on egg production performance and egg quality of laying hens. South African Journal of Animal Science 43:194-207.

Zhao, X.; Yang, Z. B.; Yang, W. R.; Wang, Y.; Jiang, S. Z. and Zhang, G. G. 2011. Effects of ginger root (Zingiber officinale) on laying performance and antioxidant status of laying hens and on dietary oxidation stability. Poultry Science 90:1720-1727. 